\title{
The Effects of Toxic Leadership on Teaching and Learning in South African Township Schools*
}

\author{
Vimbi P. Mahlangu \\ Faculty of Education, Department of Education Management and Policy Studies, Groenkloof \\ Campus, University of Pretoria, South Africa \\ E-mail: vimbi.mahlangu@up.ac.za
}

KEYWORDS Toxic Leadership. Trust. School Governing Body. School Principal. Dysfunctional School

\begin{abstract}
In this paper toxic leadership refers to destructive leadership where the school principal and the School Governing Bodies are in constant conflict over their functions. One might think that school principals and school governing bodies are working harmoniously in schools. In some township schools, especially in Gauteng secondary schools there is a challenge experienced by both school principals and School Governing Bodies (SGBs). Trust is a critical element for effective leadership and governance in schools. In some township schools in South Africa there is a challenge experienced by both school principals and school governing bodies. Their disagreements lead to ineffective teaching and learning in schools. All other stakeholders' effectiveness in the Gauteng Township schools depends on the leadership of the school principals and the School Governing Bodies. The negative effects of toxic leadership on teaching and learning in schools are the following, namely: poor working relationship between stakeholders; dysfunctional schools; poor teaching and learning; neglect of duty by stakeholders; abuse of power by school principal and SGBs; inadequate resources; no mutual trust; fear; unregulated freedom; and unacceptable behavior This is not an exhaustive list.
\end{abstract}

\section{INTRODUCTION}

Relatively few studies have focused exclusively on the effect of toxic leadership on teaching and learning in township schools in South Africa. All humans are connected with other humans through the cultural communities that contribute to their identity. Human beings are persons in so far as they are engaged in relationships. For those people who are engaged in education the work of education is for human development and empowerment. Principal leadership is needed to coordinate the work and relationships of the groups into a consistent horizontal and vertical pattern of performance that is responsive to the goals, core values and the very mission of the school.

In terms of Section 16(2) of the South African Schools Act, No.84 of 1996, a governing body stands in a position of trust towards the school. Section 16A of SASA requires the school principal to assist the governing body with the administration of school funds, take reasonable steps to prevent any financial maladministration as well as to take part in any committee or delegation which deals with any matter that has financial implication for the school.

*This paper emanates from a paper which was presented at the International Symposium on Education Reform in China, June 2011.
To whom is the principal loyal and accountable? Is it the Head of Department in the Province or the school governing body of the school? These are some of the questions that are frequently asked in schools by some School Governing Body members and these questions lead to conflict that leads to poor teaching and learning.

For an example, in the Schoonbee and others $v$ MEC for Education, Mpumalanga and Another 2002(4) SA877 (T) the assumption was that the school principal is accountable to the Head of Department in matters pertaining to school funds. The principal and the deputy principal of Ermelo high school were suspended by the Head of the provincial Department of Education on alleged charges of misusing school funds. The judge in this case, Judge Dikgang Moseneke, found that the principal is accountable to the governing body and it is the governing body that should hold the school principal accountable for financial and property matters that are not specifically entrusted to the school principal by statute. This state of affairs brought conflict in some township secondary schools.

Toxic leadership destroys a basic human sense of trust that is critical for working relationships, and effective leadership in schools. Leadership is increasingly being seen as an organizational -wide phenomenon where collec- 
tive or distributed leadership is a contributor to organizational growth and success. In some township secondary schools in Gauteng Province there are problems between the principal and SGBs.

\section{Statement of the Problem and Research Questions}

In some township secondary schools in Gauteng Province of South Africa, there appears to be a problem between the school principal and the School Governing Bodies. They have a problem in differentiating between the principal's functions and those of the SGBs. Toxic relationships affect teaching and learning in those schools. Teachers and learners are demotivated due to the conflicts that exist between the school principal and the School Governing Bodies. This paper seeks to ask the following critical questions namely:

What is the role and functions of the school principal in the School Governing Body?

What is the role and functions of the School Governing Body?

What are the effects of the relationship problems between the school principal and the School Governing Bodies on learners, teachers, and parents and on the community?

How can schools manage the toxic leadership roles of both the principal and the School Governing Bodies?

\section{RESEARCH DESIGN}

In investigating the effects of toxic leadership on teaching and learning, a qualitative approach was used. A qualitative approach is the type of educational research, in which the researcher relies on the views of participants; asks broad, general questions; collects data consisting largely of words or texts from participants; describes and analyses these words or themes and conducts the inquiry in a subjective, manner (Creswell 2008: 46). Methods used in gathering information include, amongst others, literature review, questionnaires, and interviews. A literature review was conducted to be able to interpret and summarise information from published sources available in establishing current knowledge that supports arguments in this article. This paper uses interviews because they have high response rate, particularly if few par- ticipants are involved and that both verbal and non-verbal behavior can be observed because of the face-to-face nature of the communication between the interviewer and the informants (McMillan and Schumacher 1989: 242). Travers (2001: 3 ) continues to suggest that through interviews a researcher learns a lot from very little data especially when open-ended questions are asked.

Two hundred questionnaires were distributed and 153 (76.7\%) were returned by the participants. The participants consisted of principals and SGB members (educators, parents, learners, non-teaching staff, and co-opted members). The research instruments were compiled by including the biographical data of participants in section 1; section 2 contains statements regarding the governance and management of schools. In the questionnaire participants were asked to indicate their answers by encircling the number in the block which best represents their responses. This section 2 participants were expected to respond by either strongly agree, agree, uncertain, disagree and strongly agree to statements in the questionnaire. Permission to access schools was obtained from the Department of Education. Personal and telephonic appointments were made with school principals and SGB members of schools. In analyzing data, questionnaires were collected and sent to the research consultants at the University of Pretoria (Department of Statistics) for capturing the data for analysis. The researcher with the help of the consultants analysed and interpreted the data. Responses to individual questions were also analysed and compared where appropriate. The data was analysed using factor and item analysis technique. All those items which are similar were classified under one group, and then either parental or principal responses were used to interpret the data in order to get the most prominent features of relationships. Trustworthiness and reliability was done by giving some members of the sampled schools the draft document in order to check for accuracy. A pilot project was done whereby a sample of questionnaires was distributed randomly to school principals and SGB members. This was done to ensure that the questionnaire was comprehensive and to the level of the research standard, that is, to the level (that it can be understood) of the participants.

The researcher's own experiences and document analysis were also used in the compila- 
tion of this paper. The reasons why documents are used in this paper are because they are valuable sources of information in helping researchers understand central phenomena in qualitative studies (Creswell 2008: 230).

This paper also uses interviews in the collection of data because they are purposeful conversations between interviewee and interviewer (Punch 2009). The data collected from different research instruments used was analysed using item and factor analysis technique.

Two hundred questionnaires were distributed at twenty schools around Gauteng Province. The schools were chosen randomly and black township schools were my target because these schools before 1994 they did not have parents in decision making.

\section{Toxic Leadership}

These are leaders who themselves experience injustice and psychological contract violations and tend to behave abusively towards their followers. Negative leadership associated with organizational and supervisory pressure to downsize staff seems to be a 'trickle-down' phenomenon in which pressure and stress 'flows' topdown from one level to the next (Schilling 2009: 120). This is what is happening in South African township schools due to right-sizing and downsizing of teachers.

According to Reed (2004: 67), a toxic leader is the manager who bullies, threatens, and yells. There are three key elements of the toxic leader syndrome, namely: An apparent lack of concern for the well-being of subordinates; a personality or interpersonal technique that negatively affects organizational climate; and a conviction by subordinates that the leader is motivated primarily by self-interest. Wilson-Starks (2003: 2) view toxic leadership as an approach that harms people and, eventually, the company as well. In a toxic leadership environment, people are rewarded for agreeing with the boss and punished for thinking differently. In a toxic leadership environment, "yes" people are rewarded and are promoted to leadership roles, while people who more fully engage their mental resources, critical thinking, and questioning skills are shut out from decision-making and positions of influence (Wilson-Starks 2003: 2.).

Lipman-Blumen (2005: 1) is of the view that defining toxic leaders can prove vexing, at best, since one individual's toxic leader is another's heroic savior, given that context, history and perspective weigh heavily in such judgments. Scholars argue that leaders have mental models that guide their actions. At least two aspects are worthy of note in regard to mental models influencing leader behavior. The first is the lack of malleability of mental models once they have formed. They tend to be rigid and rigidity may have drawbacks since it prohibits the possibility of continuous learning from experience. The second aspect of mental models is the relative unimportance, even absence, of academic research knowledge in guiding leader actions and behavior (Dimmock 2012: 28)

\section{Trust}

This paper argues that any collective action in schools will be affected by the level of trust among its members. Trust is an expectation that another party will not act opportunistically, will be honest, and will make a good faith effort in accordance with previous commitments (Harris 2009: 160-161). It allows for open exchange of information and ideas and creates an environment in which challenges can be disclosed and addressed in schools before they escalate to unacceptable level.

According to Schmidt in (Samier and Schmidt 2010: 49) it is difficult to define the concept 'trust'. Trust means to provide valuable opportunities for the exchange of quality information. It is expectations individuals have on each other, of the organization and institutions, and of the moral social values by which they abide. Trust is based on predictability, dependability, and faith. Predictability occurs when individuals rely on established or predictable behavior and emotional responses in a given environment.

Dependability refers to trust as a personal attribute where individuals or institutions are viewed as trustworthy when their behavior is predictable and responsive to the needs of others on a routine basis. Faith reflects an emotional security in others or institutions where there is a belief that individual or institutions will keep their promises in their efforts to be responsive to the needs of stakeholders (Samier and Schmidt 2010: 50-51). In building trust the school principal must be honest, optimistic, considerate, develop leadership among staff and, in doing so, 
display trust in their abilities, to foster a culture of trusted relationships among staff, students/ learners, and parents (Gray and Streshly 2008: 111).

\section{School Governing Body}

Structures shape organisations' capacities to develop learning communities. At their best, structures enable better and deeper communication between members of learning communities (Robertson and Timperley 2011: 111). In this paper the School Governing Body is viewed as a structure responsible for governing a school.

The School Governing Body is an organ of state, created by the South African Schools Act. 'Governing body' means a governing body contemplated in section 16 (1) of SASA. The SGB has the power to govern and the principal has the power to manage. The SGB consists of the school principal, parents of learners at the school, educators at the school, staff members who are not educators, such as secretaries and gardeners, as well as the learners at the school who are in grade eight or above (Mahlangu 2005: 14).

The concepts 'School Governing Body' is intended to establish a partnership between school communities and the state for the good governance of school (Ibid 2005: 14). In promoting participative governance and professional learning communities the principal must provide opportunities for staff to play a significant role in goal setting, problem solving, and making decisions that affect their work, encourage openness in others, facilitate effective communication, encourage teacher involvement, eliminating issues of risk and threats (Gray and Streshly 2008: 111).

\section{The Functions of School Governing Bodies}

Section 16(1) of the South African Schools Act provides that the governance of a public school is vested in its governing body. The governing body stands in a position of trust (Fidei Commissum) towards the school (Davies 2005: 60 ). This body is expected to act on behalf of the school on matters pertaining governance.

Members of governing bodies must not only take notice of the Constitution (Act No.108 of 1996), but must have knowledge of the stipulations regarding governance of schools as stated in the South African Schools Act, No. 84 of
1996. The Act classifies the SGB functions into compulsory and discretionary functions. In carrying out the compulsory functions SGBs are compelled to do the work, and in carrying out the discretionary functions they have an option of doing it or not.

\section{Compulsory Functions}

The SGBs must do the following as part of their compulsory functions, namely:

Develop the mission statement of the school (section 20(1)(c); Determine the admission policy of the public school (section 5 (5); Accept a code of conduct for learners (section 8(1) and 20(1)(d); Determine times of the school day (section 20(1)(f); recommend to the principal and head of department the appointment of educators and non-educators (section 20(1)(i-j); Take all reasonable measures within its means to supplement the resources provided by the state in order to improve the quality of education provided to all learners at the school (section 36); Establish a school fund and administer it in terms of the directions issued by the provincial head of department (section 37(1); Open and maintain a banking account (section 37(3); Annually and in accordance with guidelines determined by the Member of the Executive Council of the province, prepare a budget which sets out the estimated income and expenses of the school for the following financial year (section 38(1) and submit it to a meeting of parents (section 38(2); Implement a parental decision on school fees (section 39(3); Keep records of funds received and expended by the public school as well as of its assets, liabilities and financial transactions and prepare annual financial statements as soon as possible (section 42); Appoint an auditor to audit the records and financial statements (section 43); Adopt and function in terms of a constitution (section 20(1)(b) and 18(1).

Promote the best interest of the school and strive to ensure its development through the provision of quality education to all learners in the school (section 20(1) (a). This provision could open up the way for an SGB to claim that nothing in a public school is put beyond their reach in SASA and that they could feel free to interfere in the professional management in the school. However, such an interpretation of this specific provision flies in the face of section 20(1) (e) which provides that the SGB must support 
the principal and other staff members in the execution of their professional duties.

\section{Discretionary Functions}

These are optional functions for SGBs to perform. The SGBs may:

Determine the language policy of the public school (section 6(2); Suspend a learner (section 9(1); Permit the reasonable use of the school's facilities for community, social and fund-raising purposes (section 20(2); issue rules for religious observances at the school (section 7); Enforce payment of school fees through legal processes by parents who are liable for payment in terms of section 49 (Beckmann 2002: 7-8).

\section{Allocated Functions}

SGBs may apply to the Head of Department in writing to be allocated any of the following functions, namely:

To pay for services to the school; To purchase textbooks, educational materials or equipment for the school; To maintain and improve the school's property, and buildings and grounds occupied by the school, including school hostels, if applicable; To determine the extra-mural curriculum of the school and the choice of subject options in terms of provincial policy.

\section{School Principal}

Section 16 (3) of the South African Schools Act, No.84 of 1996 and any applicable provincial law, the professional management of a public school must be undertaken by the principal under the authority of the Head of Department. In terms of the Employment of Educators Act, No.76 of 1998 the Minister of Education would be the employer of all teachers in the public service for the purposes of determining salaries and conditions of service. For all other purposes the Director-General would be considered the employer. However, the Act retained the right of governing bodies to interview and recommend teachers for employment in each school (Forgey et al. 1999: 142).

According to Mncube (2009: 35) principals are influencers of the SGB and many suggestions emanate from them, because they are always at school and know their situation; the principal is seen as the leader of the SGB, without whom nothing can be accomplished, the principal is interpreter of education policies to other stakeholders, as the principal is assumed to be better enlightened about issues in education, ensures that education policies and the curriculum are implemented, co-ordinate SGB meetings and ensures that requirements of the South African Schools Act are adhered to. Generally, principals are regarded as the representatives of the Department of Education. They act as a link and a mediator between the Department, SGB and the school.

The principal is the manager, controller, norm setter, initiator and supporter, and the person responsible for all activities in and around the school (Mahlangu 1998: 4-5). In New Zealand a school principal is the Boards' executive in relation to the school's control and management (Macpherson 1997: 151). In the South African context the school principal is the person who plays all the roles (Mahlangu 2005: 12).

The principal is also responsible for the enhancement of capacity of governing bodies. In terms of Section 19 (1) of the South African Schools Act, No.84 of 1996, out of funds appropriated for this purpose by the provincial legislature, the Head of Department must establish a programme to-

(a) Provide introductory training for newly elected governing bodies to enable them to perform their functions; and

(b) Provide continuing training to governing bodies to promote the effective performance of their functions or to enable them to assume additional functions.

S.19 (2) The Head of Department must ensure that the principal and other officers of the education department render all necessary assistance to governing bodies in the performance of their functions in terms of SASA.

\section{Functions of School Principal}

The school principal must be aware of emotional intelligence 'the ability to monitor one's own and other's feelings and emotions, to discriminate among them, and to use this information to guide one's thinking and action' (Robertson and Timperley 2011: 203). The emotional intelligence is divided into perceiving emotion, using emotion, understanding emotion, and managing emotions. The school principal must 
be able to recognise these kinds of emotional intelligences in the schools and this may help him or her in minimising the effects of toxic leadership on teaching and learning.

Principals as members of SGBs do not change their positions as employees and representatives of the employer in the schools. Their main functions are spelled out in the Personnel Management Measures (PAM) under the Employment of Educators Act, 1998. Par.4.2 of the PAM states that the purpose of the position of principal is to ensure that the school is managed satisfactorily and in accordance with relevant positions.

The core duties and responsibilities of school principals as described in the PAM include, amongst others, the following:

Being responsible for the professional management of the school; Professional leadership regarding educator staff; The development of staff training programmes; Liaising with the district office; Providing guidelines and instructions for time-tables and for the admission and placement of learners; Keeping of accounts and records and making the best use of funds to the benefit of the learners; The fair distribution of the work load among the staff; Participating in community educational activities and community development; Being a member of the SGB and providing the necessary support and assistance to the SGB.

\section{Characteristics of Successful Principal}

A successful principal assigns credit for school success to others; takes personal blame for school failures. Builds relationships-exhibits people skills openly and communicates with staff members; involve staff in decision making. Has Unwavering Resolve-S/he is relentless, aggressive, persuasive; continuously involved with primary operations of the school. Exhibits Duality of Professional Will and Personal Humility-S/he is humble yet fearless; acts as a buffer between the school and external forces. Exhibits Hedgehog Concept-S/he is passionate about student achievement; knows what the school can be best at; knows what will make the difference. Exudes a Culture of Discipline-S/he has vision focusing on student achievement; is not a micromanager; promotes teacher responsibility.

Confronts the Brutal Facts-S/he analyses and works through challenges. Has Ambition for Success of the School-S/he puts school first before personal ambitions; encourages professionalism and leadership among staff, values staff development (Gray and Streshly 2008: 5). In this paper these characteristics shown are in contrast to what toxic leaders do in their schools.

\section{The Behaviour of Toxic Leader}

Toxic leaders engage in one or more of the following behaviors, namely:

Violating the basic human rights of their own supporters and others; demoralizing; intimidating; engaging in unethical activities; deliberately feeding their followers illusions that enhance the leader's power and impair the followers' capacity to act; playing to the basest fears and needs of their followers; identifying scapegoats and inciting others to castigate them; failing to nature other leaders, including their own successors, and improperly clinging to power ((Drucker and Ito 2005: 2-4). According to Aubrey (2012) toxic leaders create lasting and enduring harm to the organisation's culture and climate. They like to succeed by tearing others down. They also want to demonstrate their superiority and dominance over their subordinates (Tavanti 2011: 129-131).

Toxic leaders have negative leadership tendencies such as insincere leadership;

treating followers unjustly; not backing followers; distorting/withholding information, practicing face saving; acting disloyally, authoritarian behavior; attacking followers personally; being inapproachable; acting inconsiderately/ ruthlessly, exploitative leadership; exerting pressure on followers; threatening/scaring followers; pushing goals and regulations; not involving/passing followers; not offering scope for followers; involving oneself too much into daily work; being inconsistent/unreliable; not bearing responsibility, being inconstant; being inauthentic/not convincing; communicating insufficiently; and not recognizing/motivating (Schilling 2009: 115).

\section{Findings and the Effects of Toxic Leadership on Teaching and Learning}

Schools are complex, unpredictable social organizations that are extremely vulnerable to a host of powerful external and internal influence.

This article found that the negative effects of toxic leadership on teaching and learning in 
schools are, amongst others, are the following, namely: poor working relationship between stakeholders. These negative effects of toxic leadership on teaching and learning in practice means that schools have inadequate resources; no mutual trust between stakeholders, dictatorship by principal/SGBs on stakeholders; autocratic leadership; poorly attended meetings and workshops; poor personnel allocation; poor teaching and learning; neglect of duty by stakeholders; and unacceptable behavior by stakeholders. All these effects have a direct influence on teaching and learning in township schools.

Ivor Sutherland CBE (former registrar of the General Teaching Council for Scotland) asked the following question: What do parents regard as the essential characteristics of the effective school? The response was there is no doubt that they would regard an effective school as a school in which their children flourishes in all respects. Parents will wish to be sure that the school is competently managed, that there are appropriate standards of pupil behavior expected and enforced, they would wish the school management to be approachable, helpful when required and able to deal quickly and efficiently with any problems and complaints. The parents would expect the effective school to welcome their support, listen to their opinions, invite their input and actively encourage them to contribute to the growth and development of the school (Sutherland in Beckmann 2011: 3). Sutherland's argument justifies why this paper is of the view that teaching and learning in schools is poor.

According to $23.53 \%$ of the respondents some of the school principals in Gauteng schools treat parents badly. That is why $15.13 \%$ of parents play no role in schools and some schools are dysfunctional. $64.66 \%$ of the respondents are of the view that poor management by school principals is the cause of dysfunctional schools in Gauteng.

$82 \%$ of the respondents are also of the view that dysfunctional schools are caused by poor governance; poor teaching and learning. $22.22 \%$ of the respondents are of the view that the SGB must not support the principals in performing their functions; neglect of duty by stakeholders-35.29\% of the respondents is of the view that school principals confuse their work with the work of the SGBs; abuse of power by school principal and SGBs-84.21\% of the respondents who took part in the research questionnaire are of the view that in those schools where the relationship between the school principal and the SGBs is not good, there is an abuse of power. Also, $39.87 \%$ of the same respondents are of the view that school principals dominate SGBs in all affairs; inadequate resources- $33.98 \%$ of the respondents is of the view that SGBs may purchase educational material. This is a problem because by law all the stakeholders should know their functions and responsibilities; no mutual trust-80,5\% of parent respondents and $100 \%$ of school principal respondents are of the view that conflict between parents and school principals is caused by mistrust; Fear-33.34\% of the respondents are of the view that learners play no role in their schools; unregulated freedom$20.27 \%$ of the respondents are of the view that school funds are misused and $18.30 \%$ of the same respondents are saying that school principals are the ones who misuse school funds, and unacceptable behaviour-33.34\% of the respondents are of the view that SGBs and school principals fight over issues during parents meetings; (Greenberg and Baron 1997; Gordon 1991; Roy 1983; Bush et al. 1989; South African Schools Act, No. 84 of 1996).

\section{CONCLUSION}

This paper argues and concludes that teaching and learning is poor in Gauteng schools, because school principals and School Governing Bodies abuse their powers; school principals manage their schools poorly; school principals confuse (mix) their work with that of School Governing Bodies; there is a mistrust between school principals and School Governing Bodies; and generally learners play no role in the schools.

The use of the eight basic competencies can be the answer to manage the toxic effects of toxic leadership on teaching and learning in township schools. These competencies are the management of trust (credible, legitimate, honest), attention (focus others on values, ideas, goals, purpose), meaning (connect teachers, learners, parents to feel valued), self (self-knowledge), paradox (bring together ideas that seem to be at odd with each other), effectiveness (focus on developing capacity), responsibility and followup. It is of vital importance that the principal sets aside time for reading, analysis, discussion 
and leading dialogues on the school's basic values and goals. This can help both the school principal and the School Governing Bodies to understand their responsibilities and functions. Toxic leaders should emulate successful school principals, because these school principals assign credit for school success to others; take personal blame for school failures; exhibit people skills; openly communicate with staff members; involve staff in decision making; humble yet fearless; act as a buffer between the school and external forces; are passionate about student achievement; know what the school can be best at; know what will make the difference ; put the school first before personal ambitions; encourage professionalism and leadership among staff, value staff development; Have vision focusing on student achievement; are not micromanagers; promote teacher responsibility; and analyse and work through challenges.

\section{REFERENCES}

Aubrey DW 2012.The Effects of Toxic Leadership: United States Army. United States: Army War College.

Beckmann JL 2002. The Legal Position of the Principal as SGB Member and Employee of the Department of Education. Paper read at the Principal's Conference, Oppenheimer Theatre, Welkom, 24 April 2002.

Beckmann JL (Ed.) 2011. Effective Schools in Effective Systems. Proceedings of the $6^{\text {th }}$ Annual ISER Conference South Africa 2010, held in Boksburg and White River, South Africa, 19-21 July 2010.

Bush T, Kogan M, Lenny T 1989. Directors of Education: Facing Reform. London: Jessica Kingsley Publishers.

Creswell JW 2008. Educational Research, Planning, Conducting, and Evaluating Quantitative and Qualitative Research. $3^{\text {rd }}$ Edition. United States of America, New Jersey: Pearson Merrill Prentice Hall.

Davies EH 2005. Administration of the Education System and Governance. Pretoria: Centre for Education Law and Education Policy.

Dimmock C 2012. Leadership, Capacity Building and School Improvement:Concepts, Themes and Impact. Routledge: London.

Drucker PF, Ito M 2005. Toxic Leadership: A Conceptual Framework. Graduate School of Management. Claremont Graduate University. Encyclopedia of Executive Governance, 2005

Forgey H, Jeffery A, Sidiropoulos E, Smith C, Corrigan T, Mophuthing T, Helman A, Redpath J, Dimant T 1999. South Africa Survey 1999/2000 Millennium Edition. Johannesburg: South African Institute of Race Relations.
Gordon JR 1991. A Diagnostic Approach to Organisational Behavior. $3^{\text {rd }}$ Edition. London: Allyn and Bacon.

Gray SP, Streshly WA 2008. From Good Schools to Great Schools: What Their Principals Do. USA: Corwin Press.

Greenberg J, Baron RA 1997. Behavior in Organisations. $6^{\text {th }}$ Edition. USA: Prentice-Hall.

Harris A (Ed.) 2009. Distributed Leadership: Different Perspectives. Studies in Educational Leadership 7. London: Springer:

Huber SG (Ed.) 2010. School Leadership-International Perspectives. London: Springer:

Lipman-Blumen J 2005. The Allure of Toxic Leaders: Why We Follow Destructive Bosses and Corrupt Politicians - and How We Can Survive Them. New York: Oxford University Press.

Mahlangu VP 1998. The Management of Militant Teachers Organisation Members. Masters Dissertation. Pretoria: University of Pretoria.

Mahlangu VP 2005. The Relationship between the School Principal and the School Governing Body. PhD Thesis. Pretoria: University of Pretoria.

McMillan J, Schumacher S 1989. Research in Education: A Conceptual Introduction. $2^{\text {nd }}$ Edition. Scott, United States of America: Foreman and Company.

Macpherson R (Ed.) 1997. International Studies in Educational Administration, Vol.25(2). New Zealand: Commonwealth Council for Educational Administration.

Mncube V 2009. Perceptions of the principal's role in democratic school governance in South Africa. Journal of Educational Administration and History, 41(1): 29-43.

Punch KF 2009. Introduction to Research Methods for Education: Publications. London: Sage Publishers.

Reed GE 2004. Toxic leadership. Military Review Journal, 84(4): 67-71.

Republic of South Africa 1996. South African Schools Act, No.84 of 1996. Pretoria: Government Printers

Robertson J, Timperley H 2011. Leadership and Learning. London: Sage.

Roy W 1983. Teaching under Attack. London: Croom Helm.

Samier EA, Schmidt M (Eds.) 2010. Trust and Betrayal in Educational Administration and Leadership. London: Routledge.

Schilling J 2009. From Ineffectiveness to Destruction: A Qualitative Study on the Meaning of Negative Leadership. Germany: Sage Publication-RWTH Aachen University.

Tavanti M 2011. Managing Toxic Leaders: Dysfunctional Patterns in Organizational Leadership and How to Deal with Them. From <http: //works. bepress. com/marcotavanti/32.> (Retrieved on 4 March 2014).

Travers M 2001. Qualitative Research through Case Studies. London, Thousand Oaks: Sage Publication.

Wilson-Starks KY 2003. Toxic Leadership Transleadership. Transleadership, Inc., From <www .transleadership. com> 